\title{
Influence of P-Ca on cytokinins in xylem sap and on stomatal resistance in apple
}

\section{Influencia del P-Ca sobre citocininas en savia de xilema y en resistencia estomática}

\author{
en manzano
}

\section{Homero Ramírez ${ }^{1:}$ ] \\ Aarón Isain Melendres- \\ Alvarezº, \\ Alejandro \\ González ${ }^{2}$ (]) \\ Diana Jasso-Cantú ${ }^{3}$ ] \\ José Ángel Villarreal-}

Quintanilla 4

${ }^{1}$ Departamento de Horticultura. Uni-

versidad Autónoma Agraria Antonio

Narro, Calzada Antonio Narro 1923

Buenavista, Saltillo, CP. 25315

Coahuila, México.

${ }^{2}$ Riego y Drenaje. Universidad

Autónoma Agraria Antonio Narro,

Calzada Antonio Narro 1923, Bue-

navista, Saltillo, CP. 25315, Coahuila

México.

${ }^{3}$ Fitomejoramiento. Universidad

Autónoma Agraria Antonio Narro,

Calzada Antonio Narro 1923, Bue-

navista, Saltillo, CP. 25315, Coahuila,

México.

${ }^{4}$ Botánica. Universidad Autónoma Agraria Antonio Narro, Calzada Antonio Narro 1923, Buenavista, Saltillo, CP. 25315, Coahuila, México.

*Corresponding

author:

hrr_homero@hotmail.com

Scientific note

Received: May 11, 2020

Accepted: February 24, 2021

How to cite: Ramírez H, MelendresAlvarez Al, Zermeño-González A, Jasso-Cantú D, Villarreal-Quintanilla JA (2021) Influence of P-Ca on cytokinins in xylem sap and on stomata resistance in apple. Ecosistemas y Recursos Agropecuarios 8(1): e2580. DOI: 10.19136/era.a8n1.2580
ABSTRACT. With the purpose to search upon the cytokinins origin, a study was conducted on the effects of prohexadione-ca (P-Ca) on cytokinins in xylem sap and on stomatal resistance in apple. Golden Delicious seedlings were sprayed with $100 \mathrm{ppm}$ P-Ca. Stomatal leaf resistance was measured at intervals between 1 and 4 hours of spraying and 15 days after the treatment. Golden Delicious trees were sprayed with 200 ppm P-Ca two weeks after full bloom. At intervals between 1 and two weeks after P-Ca treatment, the main de-shooted stem was removed from root system and xylem sap was collected for cytokinins analysis using the suction technique. Prohexadioneca significantly increased stomatal resistance (range 2.74-4.35 s/cm ${ }^{-1}$ ) when compared to control (range 2.12-3.44 s/cm ${ }^{-1}$ ); however, P-Ca did not modify the level of cytokinins in xylem sap since range values were between 0.10 to $0.20 \mu \mathrm{g}$ kinetin equivalents $/ 20 \mathrm{ml}$ xylem sap for both, cytokinin and control.

Key words: Deciduous fruit, growth retardant, hormone translocation, leaf approach.

RESUMEN. Para investigar el origen de las citocininas, se estudió los efectos de prohexadiona de calcio ( $\mathrm{P}-\mathrm{Ca}$ ) sobre citocininas en savia de xilema y en la resistencia de estomas en manzano. Plantas Golden Delicious fueron asperjadas con 100 ppm P-Ca y la resistencia de estomas en sus hojas fue medida a intervalos de 1 a 4 horas y 15 días posteriores. Arboles Golden Delicious fueron asperjados dos semanas después de floración con 200 ppm P-Ca. Entre una y dos semanas después del tratamiento, el tallo fue removido del sistema radicular; y, la savia de xilema extraída con la técnica de succión para analizar citocininas. P-Ca aumentó significativamente la resistencia de estomas (rango 2.74-4.35 s/cm ${ }^{-1}$ ) al compararse con el testigo (rango 2.12-3.44 s/cm ${ }^{-1}$ ); sin embargo, no modificó citocininas en savia del xilema. El nivel entre testigo y P-Ca siempre fluctuó en los rangos de 0.10 a $0.20 \mu \mathrm{g}$ kinetin equivalentes $/ 20 \mathrm{ml}$ xilema.

Palabras clave: Frutal templado, perfil foliar, retardante del crecimiento, translocación hormonal. 


\section{INTRODUCTION}

It has been shown that the application of prohexadione-ca on apple trees promotes the formation of fruit buds and increases the levels of cytokinins in developing fruit seeds (Rademacher 2010, Costa and Botton, 2018, Manmohan et al. 2020). Moreover, the results of the application of exogenous cytokinins to the cut petiole of spur tissue in apple indicate that a considerable proportion of the applied hormone is transported to the bourse-bud (Ramírez et al. 2005, Nečas et al. 2018, Bradshaw et al. 2020). These experiences support the hypothesis that cytokinins may play a crucial role in the process of flower bud formation in apple. From these reports, a question arises about the origin of endogenous cytokinins, particularly at the time they are present in high levels in developing seeds.

It was suggested that the source of cytokinins found in the developing fruit seeds were the seeds themselves. However, because cytokinins and other hormones have been detected in xylem sap of apple trees (McElrone et al. 2018), the roots are considered to be one major source of these hormones (Ramírez et al. 2017, Costa and Botton, 2018). Ramírez (2000) and Theron (2021) have also suggested that the effects of growth retardants could be mediated through an effect on roots synthesized cytokinins. Therefore, since the origin of cytokinins at each stage of development in apple has not been clarified it was decided to examine the cytokinin levels in xylem sap as a mesaure of their synthesis in roots during the period following full bloom, and to determine the effect of a P-Ca spray on cytokinins in xylem exudate. The effect of P-Ca on stomatal resistance was also studied to relate the effect of the retardant on water movement in the xylem and therefore, possible effects on cytokinin movement from roots to shoots.

\section{MATERIALS AND METHODS}

This study was conducted at facilities in an experimental fruit trees plot, greenhouse and in laboratories belonging to Universidad Autónoma
Agraria Antonio Narro, in Saltillo, Coahuila, Mexico.

\section{Stomatal resistance}

Six apple seedlings of the cultivar Golden Delicious growing in pots in the greenhouse were sprayed with 100 ppm P-Ca in june 2018. Six control seedlings were sprayed with water at the same time. Experimental plants were distributed in a complete randomized design using one plant as a replicated experimental unit. Four leaves/seedling borne in the middle of the stem were selected and stomatal resistance (obtained from the mean of five readings/leaf) measured at intervals between $4 \mathrm{~h}$ of spraying and 15 days after the treatment. The measurements of stomatal resistance were made using a portable MK II Delta-T automatic porometer. The instrument was calibrated against a set of four perforations of known diffusive resistances in a polyproylene plate. All readings were taken between 10 and $12 \mathrm{~h}$ during june 2018. The results obtained were analyzed using the statistical program 'RStudio' for Windows version 10 and the data obtained was subjected to a comparison of means with the Student's test $(p=$ 0.01).

\section{Cytokinins in xylem sap}

Sixty four, four years old Golden Delicious/MM106 trees were distributed in a two blocks design with eight replicates per treatment. Thirty two trees were sprayed with $\mathrm{P}-\mathrm{Ca}$ at a concentration of 200 ppm two weeks after full bloom in 2018. Control trees were sprayed with water at the same time. At intervals between 1 and 15 days after the P-Ca treatment, the main de-shooted stem $(50-60 \mathrm{~cm}$ long and approx. 3-4 cm in diameter at the base) was removed from the root system of experimental trees. Xylem sap was collected using the technique modified by Ramirez (2014). Stems were stripped of bark for $5 \mathrm{~cm}$ from the base and set in a rubber bung in a xylem sap extractor consisting of glass manifolds which allow sap to be extracted from 5 stems at the same time (Figure 1). Sap was extracted by reducing the pressure in the extractor to $15 \mathrm{~cm} \mathrm{Hg}$ and then cutting successive sections off the distal end of the stem. Cutting was continued until each stem was cut 
down to the insertion in the rubber bung.

(A)

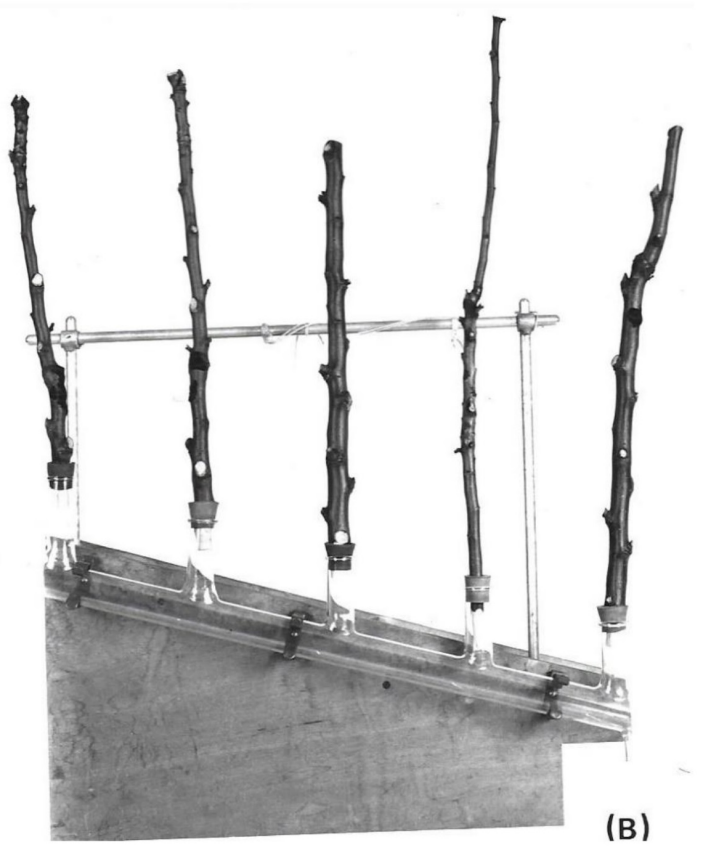

Figure 1. Xylem sap extractor consisting of a glass manifold with 5 outlets (A) end connected to vacuum pump and $(B)$ connected to collecting flask.

By removing a section about $2 \mathrm{~cm}$ long every 2-4 seconds, a steady flow of sap was obtained. Sap was collected in a $250 \mathrm{ml}$ flask placed in the other end of the extractor. After collection, sap was filtered and immediately frozen to await analysis. The extraction and purification method for cytokinins in xylem sap is given in figure 2. The content of cytokinins was determined using the Amaranthus bioassay (Biddington and Thomas 1973). The results were analyzed using the statistical program 'RStudio' for Windows version 10 and the data obtained was subjected to a comparison of means with the Student's test $(p=$ $0.01)$.

\section{RESULTS AND DISCUSSION}

\section{Stomatal resistance}

The stomatal resistances of the leaves of Golden delicious apple seedlings are presented in Table 1. Plants treated with P-Ca showed an in- crease in stomatal resistance, an effect which remained significant between $4 \mathrm{~h}$ after treatment $(4.35$ $\left.\mathrm{s} / \mathrm{cm}^{-1}\right)$ until 6 days after spraying $\left(3.90 \mathrm{~s} / \mathrm{cm}^{-1}\right)$. The maximum control data was observed on days $2\left(3.29 \mathrm{~s} / \mathrm{cm}^{-1}\right)$ and $15\left(3.40 \mathrm{~s} / \mathrm{cm}^{-1}\right)$; however, these stomatal resistance levels were below the $\mathrm{P}-\mathrm{Ca}$ treated samples. The effect of the growth retardant was greater $(p=0.01)$ at 3 and 6 days after the treatment and by 15 days the stomatal resistance was similar to the controls.

\section{Cytokinins in xylem sap}

Table 2 shows the content of endogenous cytokinins found in the xylem sap stream. It can be seen that the level of these hormones remains low in control and $\mathrm{P}$-Ca sampling tissue throughout the evaluation days. The values ranged 0.10 and 0.20 $\mathrm{mg}$ equivs/25 $\mathrm{ml}$ sap illustrates that the application of prohexadione-ca did not cause any significant change in the concentration of cytokinins in xylem sap.

The increase in stomatal resistance in apple seedlings sprayed with prohexadione-ca (Table 1) reinforces the report of Rademacher (2010) and Theron (2021). This response is usually followed by a reduction in the transpiration rate of plants, the mode of action of P-Ca on closure of stomata is not fully understood, but it has been explained in terms of changes in internal $\mathrm{CO}_{2}$ concentration in the tissues (Orton and Mansfield 1976, Nečas et al. 2018).

The content of cytokinin in the xylem sap of control samples was very low at all collection times. This has been reported previously by Ramírez et al. (2005). In xylem sap, the highest levels of cytokinin, which presumably originates in the roots, occurs about the time of full bloom and then drops off rapidly to its mínimum value where it remains until the following spring. The samples being examined in this study were collected between 16 and 30 days after full bloom. Therefore, it was expected that low cytokinin values would be obtained in control samples.

Skene (1968), Ramírez et al. (2014), Costa and Botton (2018) and Manmohan et al. (2020) proposed that growth retardants may increase the synthesis of cytokinins in the roots of fruit species. They obtained higher levels of root synthesized cytokinins 


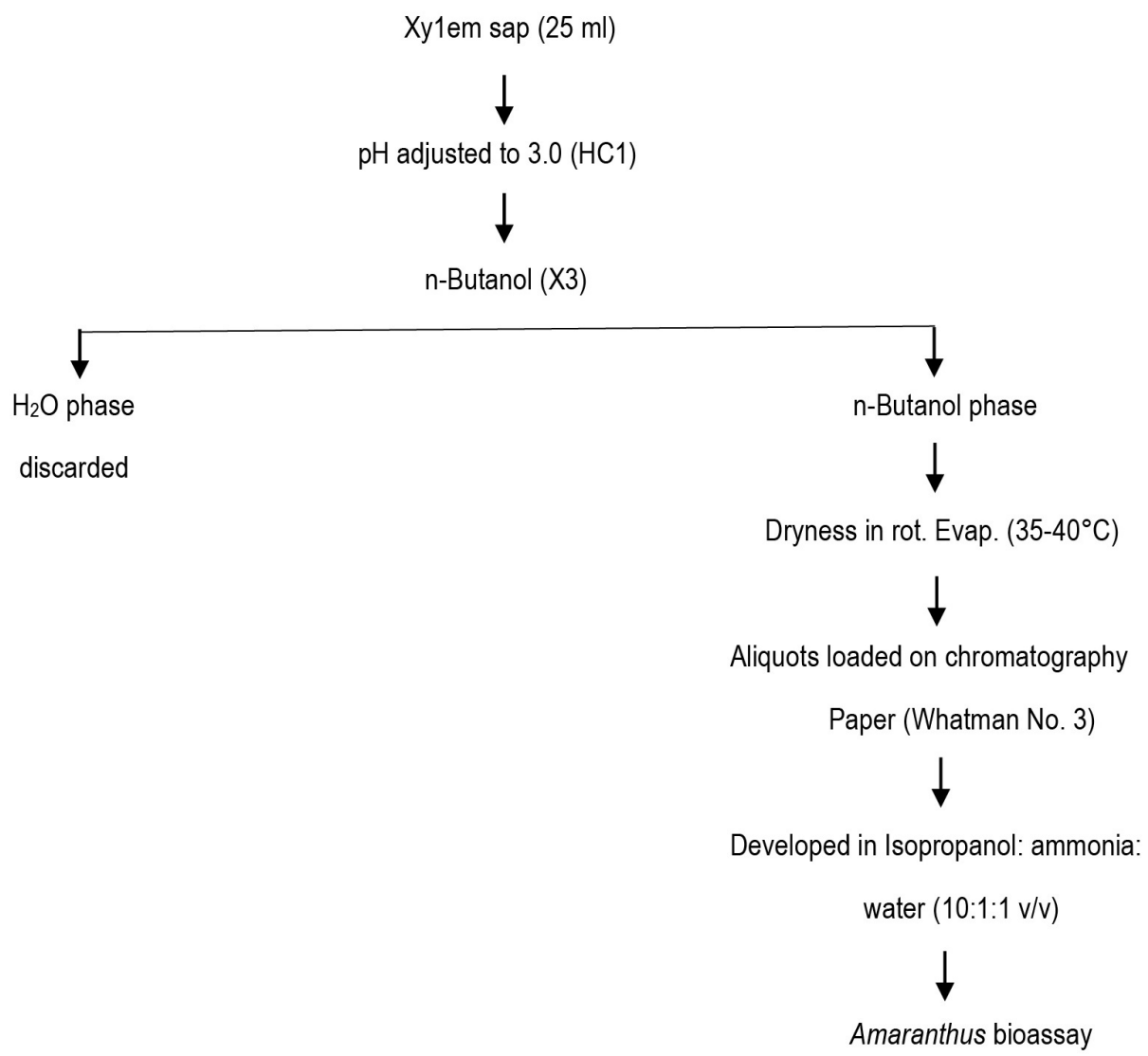

Figure 2. Flow diagram outlining procedure for the extraction and purification of Golden delicious apple xylem sap samples prior to Amaranthus bioassay for cytokinins.

Table 1. Effect of P-Ca application (100 ppm) on stomatal resistance $\left(\mathrm{sec} . \mathrm{cm}^{-1}\right)$ of Golden Delicious apple seedlings.

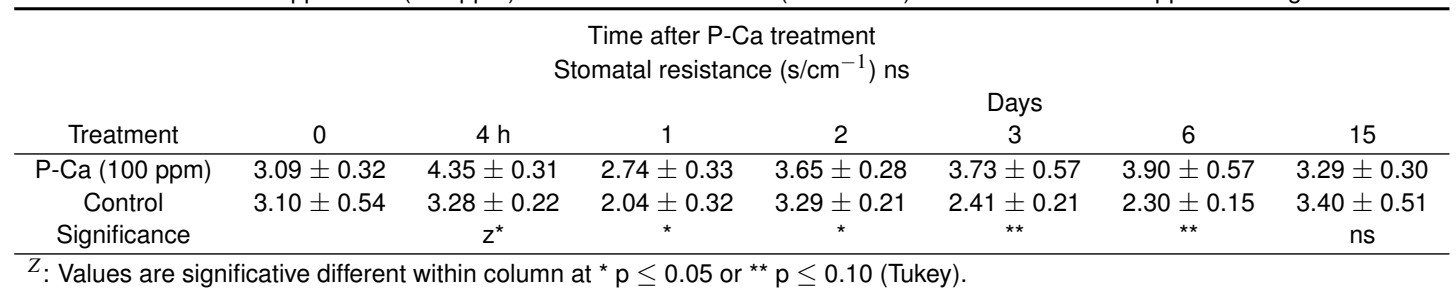

Table 2. Effect of P-Ca (200 ppm) sprayed 2 weeks after full bloom on cytokinin levels in xylem sap of Golden Delicious trees. Each value represents the mean of 8 replicate samples.

\begin{tabular}{cccccc}
\hline \multicolumn{7}{c}{ Time after P-Ca treatment } \\
Kinetin content (mg equivs/ $25 \mathrm{ml}$ sap) ns \\
Days \\
Treatment & 15 & 16 & 18 & 21 & 30 \\
\hline P-Ca $(200 \mathrm{ppm})$ & 0.20 & 0.20 & 0.10 & 0.20 & 0.20 \\
Control & 0.10 & 0.10 & 0.10 & 0.10 & 0.10 \\
\hline${ }_{n s}:$ Not significant. & & & &
\end{tabular}

in xylem sap of Vitis when CCC (Cycocel) was applied to the growing medium. However, the lack of an effect of P-Ca on cytokinins in the xylem sap of apples (Table 2) suggests that the response will depend either on the way in which the chemical is applied, or that the increase in cytokinin level is a specific response to $\mathrm{CCC}$ and $\mathrm{P}-\mathrm{Ca}$. The rapid translocation of prohexadione-ca around apple trees after foliar application (Martin et al. 1964, Theron, 2021) indicates that the lack of a response was not due to 
failure of the compound to reach the roots. On the other hand, the fact that P-Ca increases stomatal resistance (Table 1) must mean that transpiration rate, and hence the water flux in the xylem from roots to leaves, is reduced (McElrone et al. 2018). If cytokinins are loaded into xylem sap in the roots, then there should be a corresponding reduction in the rate of loading to account for the absence of an increase in concentration of cytokinins in the sap. Loading may be affected by the presence of $\mathrm{P}-\mathrm{Ca}$ in the tissue, but there might well be a self-regulatory system which maintains a constant low concentration of cytokinins in xylem sap regardless of transpiration rate.

Thus, the results in the present work support the hypothesis postulated, that the high levels of cytokinins found in other tissues like fruit seeds of trees treated with P-Ca (Ramírez et al. 2014, Bradshaw et al. 2020) originated in situ and were not translocated there from the roots.

\section{LITERATURE CITED}

Biddington JA, Thomas TH (1973) A modified Amaranthus betacyanin bioassay for the rapid determination of cytokinins in plant extracts. Planta 111: 183-186.

Bradshaw TL, Foster J, King-Richards SL (2020) Plant growth regulators do not reduce biennial bearing of two cider apple cultivars in Vermont, USA. Acta Horticulturae 1281: 273-278.

Costa G, Botton A (2018) Dealing with plant bioregulators in Italy: from the introduction to now. Acta Horticulturae: 1206: 1-12. DOI: 10.17660/ActaHortic.2018.1206.1

Manmohan L, Mir MM, Umar L (2020) Influence of prohexadione calcium and paclobutrazol on growth, yield and mineral content of pear cultivar Clapp's favorite. International Journal of Chemical Studies 8: 256-259.

Martin GC, Williams MW, Batjer LP (1964) Movement and fate of labelled N-dimethyl-amino-succinic acid (Bnine), a size controlling compound in apple seedlings. Proceedings American Society for Horticulture Sciences 84: 7-13.

McElrone AJ, Earles JM, Knipfer TM, Albuquerque CP, Brodersen CR, Cuneo IF (2018) Changes in xylem conducting capacity and water storage across species: how can variable air content of xylem cells affect sap flow? Acta Horticulturae 1222: 5-12.

Nečas T, Wolf J, Kiss T, Láćík J, Letocha T (2018) Use of different plant growth regulators for control of shoot branching in apple and pear trees. Acta Horticulturae 1206: 225-232.

Orton PJ, Mansfiel TA (1976) Studies of the mechanism by which daminozide (B9) inhibits stomatal opening. Journal Experimental Botany 27: 125-133.

Rademacher W (2010) Dealing with Plant Bioregulators: An Industrial View. Acta Horticulturae 884: 717-724.

Ramírez H (2000) Endogenous cytokinins and fruit bud formation in apple. Acta Horticulturae 514: 245-248.

Ramírez H, Peralta MR, Benavides A, Sánchez LA, Robledo V, Hernandez J (2005) Efecto de P-Ca en tomate y su relación con la variación de la concentración de giberelinas y citocininas. Revista Chapingo serie Horticultura 11: 283-290.

Ramírez H, Sánchez-Canseco JC, Ramírez-Perez LJ, Benavides A (2014) Significance of hormones on flower bud initiation and fruit quality in apple. Our expertise. Acta Horticulturae 1042: 73-77.

Ramírez H, Alvizo-Medrano BY, Melendres-Alvarez Al, Jasso-Cantú D, Villarreal-Quintanilla JA, Rodríguez-García $R$ (2017). Pomological characteristics and gibberellins identification On golden Delicious apple mutants. Acta Horticulturae 1206: 43-50. 
Skene KGM (1968) Increases in the levels of cytokinins in bleeding sap of Vitis vinifera L. after CCC treatment. Science 159: 1477-1478.

Theron, KI (2021) The use of plant growth regulators to manipulate European pear crop load. Acta Horticulturae 1301: 273-278. 